\title{
Influence of Tryptophan on the growth, yield and quality of chilli with and without fertilizer
}

Saeed Ur Rahman ${ }^{1}$, Ghulam Nabi ${ }^{1}$, Muhammad Noman Khan ${ }^{1}$, Faraz Ali Shah $^{1 *}$, Shah Rukh ${ }^{1}$, Wajid Ali ${ }^{1}$, Mujeeb Ur Rahman ${ }^{1}$, Shah Zaib ${ }^{1}$ and Muhammad Hilal ${ }^{1}$

1. Department of Horticulture, The University of Agriculture, Peshawar-Pakistan

*Corresponding author's email: farazali736@gmail.com

Citation

Saeed Ur Rahman, Ghulam Nabi, Muhammad Noman Khan, Faraz Ali Shah, Shah Rukh, Wajid Ali, Mujeeb Ur Rahman, Shah Zaib and Muhammad Hilal. Influence of Tryptophan on the growth, yield and quality of chilli with and without fertilizer. Pure and Applied Biology. Vol. 10, Issue 4, pp1287-1302.

http://dx.doi.org/10.19045/bspab.2021.100134

\begin{tabular}{llll}
\hline \hline Received: 26/12/2020 & Revised: 20/02/2021 & Accepted: 28/02/2021 & Online First: 05/03/2021 \\
\hline \hline
\end{tabular}

\section{Abstract}

The influence of Tryptophan on the growth, yield and quality of chilli with and without fertilizer was studied at AMK Research Farm Mardan, during 2019. The experiment was laid out in RCBD with a split plot arrangement having three replications. Factor-A consisted of two treatments i.e., fertilizers applied ( $100 \mathrm{~kg} \mathrm{~N}, 60 \mathrm{~kg} \mathrm{P}_{2} \mathrm{O}_{5}$ and $\left.25 \mathrm{~kg} \mathrm{~K}_{2} \mathrm{O} \mathrm{ha}^{-1}\right)$ and without fertilizer was assigned into main plots whereas, Factor-B was Tryptophan levels $\left(0.0,0.5,1.0,1.5,2.0\right.$ and $\left.2.5 \mathrm{mg} \mathrm{L}^{-1}\right)$ which was allotted to sub-plots. It was revealed from the study that those plants which were treated with the application of NPK fertilizer; produced taller plants $(80.88 \mathrm{~cm})$, more branches plant ${ }^{-1}$ (7.44), stem diameter $(1.67 \mathrm{~cm})$, leaf area $\left(51.88 \mathrm{~cm}^{2}\right)$, early flowering $(37.08$ days), early fruit harvesting (58.88 days), maximum fruits plant $^{-1}$ (293.06), least fruit drop (53.61\%), fruit weight (3.58 g), fruit yield (5.86 tons ha $\left.{ }^{-1}\right)$, total soluble solids (5.39 ${ }^{\circ}$ Brix) and ascorbic acid contents

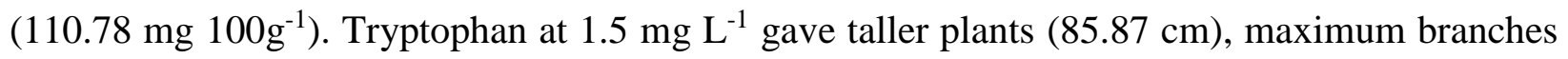
plant $^{-1}(8.85)$, stem diameter $(1.70 \mathrm{~cm})$, leaf area $\left(57.71 \mathrm{~cm}^{2}\right)$, earlier flowering (39.54 days), early fruit harvesting (57.16 days), more fruits plant ${ }^{-1}$ (318.17), least fruit drop (38.80\%), maximum fruit weight $(4.13 \mathrm{~g})$, fruit yield $\left(7.25\right.$ tons ha $\left.^{-1}\right)$, total soluble solids $\left(5.60{ }^{\circ}\right.$ Brix $)$ and ascorbic acid contents $\left(115.33 \mathrm{mg} 100 \mathrm{~g}^{-1}\right)$ of chilli. It was concluded that Tryptophan along with NPK fertilizer application produced better plant growth, fruit yield and quality of chilli, under the climatic conditions of Mardan.

Keywords: Chilli growth; NPK fertilizer; Tryptophan; Yield

Introduction

Chilli belongs to the genus Capsicum, specie аппиит. It is one of the members of
Solanaceae family and it is has been cultivated in tropical and subtropical climates. South and Central America are 
considered as its origin [1]. After tomato and potato, it is the $3^{\text {rd }}$ most important crop in the genus Capsicum [2]. Chilli grows well in a different part of Pakistan where the danger of frost is minimum [3]. The optimum required temperature for chilli production is $20-25^{\circ} \mathrm{C}$ [4]. Chilli can be consumed as a salad and dried condiments. In Pakistan there are two species of chilli that grow commercially i.e., Capsicum annum and Capsicum frutescens [5]. Chillies are grown as vegetable and condiments [6]. In developed countries, chilli is used as an insecticide [7].

Chillies have high nutritional value, and source of vitamin A, C, E and B complex along with minerals like $\mathrm{P}, \mathrm{Mo}$ and $\mathrm{Mn}$. Chilli is one of the most special vegetable that having seven times more vitamin $\mathrm{C}$ than orange [8,9]. From an area of about 212 million ha, the total world production of capsicum was about 36.46 million metric tonnes. The major producing country of chilli is china that contributing $36 \%$ of the world's cultivated area with a production of 12.53 million tonnes. India contributes an average yearly production of 0.9 million tonnes from 1.85-million-hectare area with a production of 1.8 tones $\mathrm{ha}^{-1}$ [10]. However total production of chillies in Pakistan from an area of 65,275 hectares was 148,114 tonnes, out of which Khyber Pakhtunkhwa contributed 319 ha area with the production of 360 tones [11].

Chilli has the potential to grow on different soils; however, the suitable soil that is considered best for its production is sandy to loam soils. The $\mathrm{pH}$ of the soil ranges from 5.0-6.0 but can be cultivated on soil $\mathrm{pH}$ ranges from 5.0-6.8 for chillies production [12]. In general, fruit and flower drop are one of the serious problems of chilli due to which their yield is decreasing that is because of physiological and hormonal imbalances in the plant, apart from this, the main cause is an unfavourable condition such as extreme temperature [13].

Tryptophan (TRP) is termed as the precursor of the phytohormone, and is used by the living bacteria for the purpose of indole acetic acid production [14]. Tryptophan had more influence on the growth and yield attributes rather than pure auxins [15]. Tryptophan was compared with pure Auxin, they found a significant effect on the growth of radish at a low concentration at the seedling stage [16]. Auxin is a key plant hormone, helps in root induction, also helps in cell division, cell enlargement, apical dominance, vascular tissue differentiation, flowering, abscission of leaves and fruits, senescence of leaf and also has a key role in fruit setting [17].

Application of Nitrogen (N) to chillies helps in increasing plant growth characters like nutrient content, colour of leaves as well as yield [18]. The yield was also improved with the increased rate of nitrogen application, but the excess application of nitrogen encouraged vegetative growth, as result the yield gets decreases [19]. Phosphorous (P) helps in plant growth and development. Phosphorous involves the plant functions like energy transformation, photosynthesis, starches and sugars transferring and the nutrients translocation within the plant, hence proper phosphorous application is required for better plant growth and yield [20]. Potassium $(\mathrm{K})$ is important for plant metabolism like water relation translocation, photosynthesis and also activation of the enzyme. Although, $\mathrm{K}$ is 
not a component of any plant structures, but it plays a key role in essential regulatory processes of the plant such as plant stomata regulation and water use, regulation of enzyme activities, processes of Osmoregulation, translocation of sugars, carbohydrates formation, plant energy status, synthesis of protein and all other essential processes that help plants for better growth and reproduction [21].

In view of the above importance of Tryptophan and fertilizers (NPK), the objectives of the study were to find the optimum dose of Tryptophan for chilli crop and to study the influence of combined treatment of Tryptophan and fertilizer (NPK) on the performance of chilli crop in District Mardan climate.

\section{Materials and Methods}

A trial on "Influence of Tryptophan on the growth, yield and quality of chilli (Capsicum annum L.) with and without fertilizers" was conducted in Research Farm Palatoo at AMK sub-campus Mardan, during April 2019 which lies at $34^{\circ} 20^{\prime} \mathrm{N}$ Latitude and $72^{\circ} 02^{\prime} \mathrm{E}$ Longitude.

The experimental plots were properly prepared. After levelling of experimental plots, $30 \mathrm{~cm}$ raised ridges were prepared and chilli plants were planted at 60 and $30 \mathrm{~cm}$ row to row and plant to plant spacing respectively. The experimental field was irrigated just after transplantation of chilli seedlings and further irrigations were practiced when needed. Most of the cultural practices like hoeing and weeding on regular bases were practiced uniformly in all plots.

\section{Experimental design}

Two factors Randomized Complete Block Design was used with split plot arrangement. Each treatment was replicated three times. The field was distributed into three blocks (for three replications) and each replication had two main plots and 12 sub-plots, as a result, the total number of was 36 and each plot size was $1.8 \mathrm{~m}^{2}$. There were 2 rows in each plot and each row had 4 plants.

NPK Fertilizer and Tryptophan

\section{Application}

A recommended dose of fertilizer i.e., N 100 $\mathrm{kg} \mathrm{ha}^{-1}$, P $60 \mathrm{~kg} \mathrm{ha}^{-1}$ and $\mathrm{K} 25 \mathrm{~kg} \mathrm{ha}^{-1}$ was used before transplantation [22]. However, nitrogenous fertilizer was applied in split doses, first dose at the time of field preparation, and the second dose after 25 days of seedlings transplanting. Tryptophan was applied as foliar application 20 days before the flowering stage (Table 1).

Table 1. Shows detail of treatments

\begin{tabular}{|c|c|}
\hline Factor A: & Factor B: \\
\hline Fertilizer NPK (Main-plot) & Tryptophan Levels mg L'-1 (Sub-plot) \\
\hline \multirow{3}{*}{ With fertilizer at $100,60 \& 25 \mathrm{~kg} \mathrm{ha}^{-1}$ respectively } & Control \\
\cline { 2 - 2 } & 0.5 \\
\cline { 2 - 2 } & 1.0 \\
\hline \multirow{2}{*}{ Without fertilizer } & 1.5 \\
\cline { 2 - 2 } & 2.0 \\
\cline { 2 - 2 } & 2.5 \\
\hline
\end{tabular}




\section{Studied parameters}

The following attributes were studied:

1. Plant height $(\mathrm{cm})$

2. Number of branches plant ${ }^{-1}$

3. Stem diameter $(\mathrm{cm})$

4. Leaf area $\left(\mathrm{cm}^{2}\right)$

5. Days to first flowering

6. Days to harvesting

7. Fruits plant ${ }^{-1}$

8. Fruit drop percentage (\%age)

9. Fruit length $(\mathrm{cm})$

10. Fruit weight $(\mathrm{g})$

11. Fruit yield (tons ha $^{-1}$ )

12. Total soluble solids $\left({ }^{\circ}\right.$ Brix $)$

13. Ascorbic acid $\left(\mathrm{mg}_{\left.100 \mathrm{~g}^{-1}\right)}\right.$

\section{Statistical analysis}

During the research work, the data were observed on different parameters that were analyzed by using Analysis of Variance technique for the purpose of difference between treatments and their contact. Where the differences were found significant then the means was compared by using LSD test. Statistics computer software 8.1 was applied for computing both, LSD and ANOVA [23].

\section{Results and Discussion}

\section{Plant height (cm)}

Mean data regarding the height of chilli plant as affected by Tryptophan with and without the application of NPK fertilizer are shown in (Table 2). Analysis of variance illustrated that plant height was considerably affected by Tryptophan with and without NPK fertilizer, and also by their interaction. Plant height as influenced by Tryptophan application, gave taller plants $(85.87 \mathrm{~cm})$ which was recorded in Tryptophan foliar spray at $1.5 \mathrm{mg} \mathrm{L}^{-1}$, whereas less taller plants $(71.61 \mathrm{~cm})$ were recorded in $0 \mathrm{mg} \mathrm{L}^{-1}$. As concerned with NPK fertilizer application, taller plants $(81.60 \mathrm{~cm})$ was recorded in NPK fertilizer applied plots, while minimum plant height $(77.04 \mathrm{~cm})$ was found without fertilizer plots. Plant height is a key morphological parameter [24]. Besides some amino acids, Tryptophan had an influence on gene expression for the production of essential macro nutrients that are specifically needed for permanent cell elongation [25]. The functions of amino acids in plants i.e., Tryptophan which is considering as a precursor of indole acetic acid and therefore IAA is promoted and encourage stimulation of cell division and cell elongation, as a result, plant height was enhanced as stated by [26]. The present findings are with the agreement of [27] that the foliar spray of Tryptophan helps in increasing plant height. Furthermore, [28] stated that an increment in the growth of the plant by the use of Tryptophan may be due to its conversion into IAA. The sufficient supply of the macronutrient i.e., NPK play a regulating role in plant morphological and physiological processes. Similar results were also reported by [29].

\section{Number of branches plant ${ }^{-1}$}

Mean values of branches plant ${ }^{-1}$ as affected by Tryptophan with and without the application of NPK fertilizer in chilli crop are shown in (Table 2). ANOVA revealed that branches plant $^{-1}$ was highly affected by Tryptophan with and without NPK fertilizer, whereas their interaction was non-significant. Mean (Table 2) showed that the plants treated with Tryptophan at $1.5 \mathrm{mg} \mathrm{L}^{-1}$ had produced more branches plant ${ }^{-1}(8.85)$, while minimum branches plant ${ }^{-1}(5.82)$ was observed in $0 \mathrm{mg}$ $\mathrm{L}^{-1}$. As concerned with fertilizer, more branches plant ${ }^{-1}$ (7.44) was found in plots 
having NPK fertilizer, while minimum branches plant ${ }^{-1}$ (7.12) was noticed in plots without NPK fertilizer. Branching of plants may play a good role in the growth and yield component of the crops. [27] found that Tryptophan application significantly improved plant growth i.e., branches of the plant. Tryptophan application can affect the growth and yield [30]. Improvement in the growth phases of the plant may be due to the conversion of Tryptophan into indole acetic acid [28]. The results showed that Tryptophan at $1.5 \mathrm{mg} \mathrm{L}^{-1}$ had significantly influenced over control at the percentage of $52.17 \%$. Distance between internodes, number of leaves, and branches plant ${ }^{-1}$ were considerably influenced by the treatment of Tryptophan over control treatment in the okra plant [31]. As concerned with NPK fertilizer, that helps in vegetative, reproductive and quality characters of the plant showed significant influence in terms of plant branching. The same results was cited by [32] that NPK fertilizer with a combination of biocompost had significantly increased primary and secondary branches.

Table 2. Plant height $(\mathrm{cm})$, Number of branches plant ${ }^{-1}$ and Stem diameter $(\mathrm{cm})$ of chilli as influenced by Tryptophan with and without the application of NPK fertilizer

\begin{tabular}{|c|c|c|c|}
\hline Fertilizer (NPK) & Plant height $(\mathrm{cm})$ & Branches plant $^{-1}$ & Stem diameter $(\mathrm{cm})$ \\
\hline With Fertilizer & $81.60 \mathrm{a}$ & $7.44 \mathrm{a}$ & $1.67 \mathrm{a}$ \\
\hline Without Fertilizer & $77.04 \mathrm{~b}$ & $7.12 \mathrm{~b}$ & $1.52 \mathrm{~b}$ \\
\hline LSD (0.05) & 2.80 & 0.21 & 0.14 \\
\hline \multicolumn{4}{|l|}{ Tryptophan $\left(\mathrm{mg} \mathrm{L}^{-1}\right)$} \\
\hline Control & $71.61 \mathrm{~d}$ & $5.82 \mathrm{e}$ & $1.46 \mathrm{c}$ \\
\hline 0.5 & $78.50 \mathrm{c}$ & $6.87 \mathrm{~d}$ & $1.60 \mathrm{~b}$ \\
\hline 1.0 & $79.98 \mathrm{bc}$ & $7.22 \mathrm{c}$ & $1.59 \mathrm{~b}$ \\
\hline 1.5 & $85.87 \mathrm{a}$ & $8.85 \mathrm{a}$ & $1.70 \mathrm{a}$ \\
\hline 2.0 & $81.50 \mathrm{~b}$ & $7.54 \mathrm{~b}$ & $1.64 \mathrm{ab}$ \\
\hline 2.5 & $78.47 \mathrm{c}$ & $7.38 \mathrm{~b}$ & $1.58 \mathrm{~b}$ \\
\hline LSD (0.05) & 2.15 & 0.15 & 0.06 \\
\hline \multicolumn{4}{|l|}{ Interaction } \\
\hline Fert*Trp & 3.04 & NS & NS \\
\hline
\end{tabular}

The mean values with different alphabets are significantly variant at 5\% probability level.

\section{Stem diameter $(\mathrm{cm})$}

Mean data for stem diameter $(\mathrm{cm})$ of chilli as affected by Tryptophan with and without the application of NPK fertilizer are presented in (Table 2). Analysis of variance indicated that stem diameter was considerably influenced by Tryptophan with and without NPK fertilizer, whereas their interaction was found non-significant. Mean (Table 2) presented that plants treated with Tryptophan application at $1.5 \mathrm{mg} \mathrm{L}^{-1}$ gave maximum stem diameter $(1.70 \mathrm{~cm})$ followed by Tryptophan at $2.0 \mathrm{mg} \mathrm{L}^{-1}$ which had produced $(1.64 \mathrm{~cm})$ stem diameter, while minimum stem diameter $(1.46 \mathrm{~cm})$ was observed in $0 \mathrm{mg} \mathrm{L}^{-1}$. As concerned with 
NPK fertilizer application, maximum stem diameter $(1.67 \mathrm{~cm})$ was found in plots having NPK fertilizer, while least stem diameter $(1.52 \mathrm{~cm})$ was noted in plots without NPK fertilizer. Stem diameter is an essential morphological parameter [24]. There was $16.26 \%$ increase in stem diameter at $1.5 \mathrm{mg}$ $\mathrm{L}^{-1}$ of Tryptophan foliar application was recorded as compared to the control treatment. [33] reported that improvement in stem diameter of okra was observed with the use of plant growth regulators. PGRs or even their precursors i.e., Tryptophan which is the physiological precursor of Auxin play a crucial role in cell division and cell elongation in the specific cambium or other plant tissues, or encouragement of growth developmental phases in the meristematic tissues [24]. The results are in support with the findings of [34] that application of NPK fertilizer to Chilli pepper gave maximum stem diameter, while least in control.

\section{Leaf area $\left(\mathrm{cm}^{2}\right)$}

Mean data for leaf area $\left(\mathrm{cm}^{2}\right)$ of chilli as affected by Tryptophan with and without the application of NPK fertilizer are revealed in (Table 3). Analysis of variance disclosed that leaf area was highly influenced by Tryptophan with and without the use of NPK fertilizer, and also by their interaction. Mean (Table 3 ) showed that leaf area as affected by foliar application of Tryptophan, the highest leaf area $\left(57.71 \mathrm{~cm}^{2}\right)$ was recorded in Tryptophan foliar application at $1.5 \mathrm{mg} \mathrm{L}^{-1}$, while the lowest leaf area $\left(40.44 \mathrm{~cm}^{2}\right)$ was recorded in $0 \mathrm{mg} \mathrm{L}^{-1}$. As concerned with NPK fertilizer, maximum leaf area $\left(52.87 \mathrm{~cm}^{2}\right)$ was noted in NPK fertilizer applied plots, while the lowest leaf area $\left(45.90 \mathrm{~cm}^{2}\right)$ was found without NPK fertilizer plots. Leaf area is one of the important trait that helps in determining the final yield of the crops. [35] reported that leaf area is an essential growth parameter that specifically helps in increasing both the growth and yield of the plants. The results making similarities with the findings of [36] who stated that leaf area development has specifically influenced by foliar application of Tryptophan and rates of synthetic fertilizer i.e., Urea, DAP and TSP. Tryptophan is the functional precursor of the phytohormones that is used by bacteria for the purpose of IAA production [14]. Auxin helps in cell division, cell elongation and induce rooting of plants [17]. Tryptophan has a stimulatory influence on initiating photosynthetic pathway that leads to the formation of chlorophyll, resulted in maximum leaf area [37]. Similar results were found by [38] when Tryptophan was applied to various crops. Furthermore [16] reported that at the seedling stage of radish, Tryptophan was found significantly positive as compared with pure auxin.

\section{Days to first flowering}

The data regarding days to the first flowering of chilli as influenced by Tryptophan with and without the application of NPK fertilizer are in (Table 3). ANOVA presented that the days to earlier flowering was considerably influenced by Tryptophan with and without NPK fertilizers, whereas their interaction effect was non-significant. (Table 3) displayed the days to first flowering as affected by foliar application of Tryptophan, least days to earlier flowering (39.54) was recorded in Tryptophan foliar application at $1.5 \mathrm{mg} \mathrm{L}^{-1}$ while maximum days to earlier flowering (47.43) was noticed in control. As concerned with NPK fertilizer application, 
least days to earlier flowering (37.08) were noted in NPK fertilizer applied plots, while a higher number of days to first flowering (45.56) was recorded without NPK fertilizer plots. Days to first flowering helps in determining the duration of the crop to fruit harvest. Induction of early flowering on plants is a key sign of increasing plant tendency to move over vegetative and become on the stage of reproductive growth with aging [39]. Foliar application of Tryptophan also allowed plant for the purpose of early flower induction. Plants treated with Tryptophan foliar application took minimum days to early flowering rather than plants untreated with a foliar spray of Tryptophan [40] further stated that application of Tryptophan instead of pure auxin guarantee the continues supply of auxin to plants. The results are similar with [41] that through the treatment of NPK fertilizer which is the major essential plant molecules, to plants considerably influenced on days taken to early flower induction. The maximum time taken to earlier flowering was observed in control, while least in plants that are treated with NPK fertilizer. He further stated that with the deficiency of macro plant nutrients i.e., NPK, there will be stunted plant growth which leads to late flowering, therefore the gradual improvement in NPK fertilizer levels helped plants in the reduction of days to early flowering. Similar findings were reported by [42] in Chilli.

Table 3. Leaf area $\left(\mathrm{cm}^{2}\right)$, Days to first flowering and Days to fruit harvesting of chilli as influenced by Tryptophan with and without the application of NPK fertilizer

\begin{tabular}{|c|c|c|c|}
\hline Fertilizer (NPK) & Leaf area $\mathbf{( c m}^{\mathbf{2}}$ ) & Days to $\mathbf{1}^{\text {st }}$ flowering & Days to harvesting \\
\hline With Fertilizer & $52.87 \mathrm{a}$ & $37.08 \mathrm{~b}$ & $58.88 \mathrm{~b}$ \\
\hline Without Fertilizer & $44.90 \mathrm{~b}$ & $45.56 \mathrm{a}$ & $63.05 \mathrm{a}$ \\
\hline LSD (0.05) & 2.47 & 8.41 & 3.53 \\
\hline Tryptophan (mg L $\mathbf{- 1})$ & \multicolumn{4}{|l}{} \\
\hline Control & $40.44 \mathrm{e}$ & $47.43 \mathrm{a}$ & $65.83 \mathrm{a}$ \\
\hline 0.5 & $45.76 \mathrm{~d}$ & $40.70 \mathrm{~b}$ & $62.25 \mathrm{ab}$ \\
\hline 1.0 & $51.15 \mathrm{~b}$ & $40.20 \mathrm{~b}$ & $61.58 \mathrm{~b}$ \\
\hline 1.5 & $57.71 \mathrm{a}$ & $39.54 \mathrm{~b}$ & $57.16 \mathrm{c}$ \\
\hline 2.0 & $51.42 \mathrm{~b}$ & $39.95 \mathrm{~b}$ & $58.58 \mathrm{bc}$ \\
\hline 2.5 & $46.83 \mathrm{c}$ & $40.08 \mathrm{~b}$ & $60.41 \mathrm{bc}$ \\
\hline LSD (0.05) & 0.91 & 3.73 & 3.76 \\
\hline Interaction & 1.29 & $\mathrm{NS}$ & $\mathrm{NS}$ \\
\hline Fert*Trp & \multicolumn{3}{|l}{} \\
\hline
\end{tabular}

The mean values with different alphabets are significantly variant at $5 \%$ probability level.

\section{Days to harvesting}

Days to fruit harvesting of chilli as influenced by Tryptophan with and without the application of NPK fertilizer are presented in
(Table 3). ANOVA showed that days to fruit harvesting was considerably influenced by Tryptophan with and without NPK fertilizer, whereas their interaction effect was non- 
significant. Plants treated with Tryptophan at $1.5 \mathrm{mg} \mathrm{L}^{-1}$ had the earliest fruit harvest (57.16 days), while late fruit harvest (65.83 days) was found in control followed by Tryptophan at $0.5 \mathrm{mg} \mathrm{L}^{-1}$ which had (62.25 days) to fruit harvesting. As concerned with NPK fertilizer application, the least days to fruit harvesting (58.88) was found in those plots having NPK fertilizer, while more days to fruit harvesting (63.05) was noted in plots without NPK fertilizer. Foliar application of Tryptophan empowering plants to flower early which resulted in minimum days taken to fruit harvesting which is the key sign of maturity that when fruits ripe and attain their proper size, then it should be harvested on the right time. [40] further cited that minimum days taken to early flowering and fruit harvesting was experienced in plants that are sprayed with Tryptophan, while more number of days was noted in plots to which Tryptophan was not added. These results are in agreement with the findings of [43] regarding various crops. The shortage of macronutrients i.e., NPK there was stunted and poor plant growth resulted in prolonged time taken to fruit setting. Early fruit maturity are helpful for attaining early cucumber yield [44]. When NPK were added to cucumber plants, resulted in early fruit maturity, while maximum days were noted in plants that are untreated with NPK fertilizer [41].

\section{Number of fruits plant $\mathbf{t}^{-1}$}

Number of fruits plant ${ }^{-1}$ of chilli as influenced by various levels of Tryptophan with and without the application of NPK fertilizer are revealed in (Table 4). ANOVA indicated the fruits plant ${ }^{-1}$ was considerably influenced by Tryptophan with and without the application of NPK fertilizer, while their interaction effect was non-significant. (Table 4) indicated that fruits plant $^{-1}$ as affected by different levels of Tryptophan, maximum fruits plant $^{-1}$ (318.17) was noted in Tryptophan application at $1.5 \mathrm{mg} \mathrm{L}^{-1}$, while least number of fruits plant ${ }^{-1}$ (272.67) was noticed in $0 \mathrm{mg} \mathrm{L}^{-1}$. As regarded with NPK fertilizer, higher number of fruits plant $^{-1}$ (293.06) found in NPK fertilizer applied plots, while least fruits plant ${ }^{-1}$ (290.89) had observed in without NPK fertilizer plots. Fruit plant ${ }^{-1}$ is a key for yield [24]. Those plants of hot pepper that was treated with Tryptophan induced maximum fruits plant $^{-1}$ than those of untreated plants [45]. The yield of tomato was also enhanced with the use of Tryptophan [46]. These experimental results are in confirmatory with the findings of [47] on strawberry; and [48] on canola plant. Foliar application of Tryptophan on chilli had produced greater fresh fruit and maximum fruits plant ${ }^{-1}$ [49]. Furthermore [41] revealed that more number of fruits per plant was observed in cucumber where NPK were used while least in control, he further described that balance amount of nutrients enhanced growth of cucumber which resulted in maximum fruits plant $^{-1}$. These results are strongly supported with the findings of [44] who found more number of fruits plant ${ }^{-1}$ in cucumber with the supply of NPK fertilizers. Possible reason for increased number of fruits is the presence of fertile flowers on plants which ultimately resulted in increased number of fruits plant ${ }^{-1}$. [50] declared the correlation among fertile flowers and fruits plant $^{-1}$. Sowing of plants on the right time helped plants like plant growth with increased fruits plant $^{-1}$, similar results were also reported by [51] in squash. 


\section{Fruit drop (\%)}

Mean data about fruit drop percentage in chilli as influenced by Tryptophan with and without the application of NPK fertilizer are shown in (Table 4). ANOVA exposed that fruit drop was considerably affected by Tryptophan with and without the use of NPK fertilizer, and also by their interaction. (Table 4) presented that fruit drop as affected by Tryptophan, minimum fruit drop (38.80) was noted in Tryptophan foliar application at 1.5

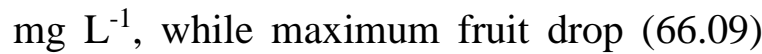
was recorded in $0 \mathrm{mg} \mathrm{L}^{-1}$. As concerned with the application of NPK fertilizer least fruit drop (53.61) was observed in NPK fertilizer applied plots, while higher fruit drop (55.10) was noticed in without NPK fertilizer plots. Before fruit harvest, fruit drop takes place which is the profitable loss of the growers [52]. Fruit drop is taking place in plants because of abscission layer [53]. Abscission layer becomes sensitive to $\mathrm{C}_{2} \mathrm{H}_{4}$ because of downfall in the level of auxin [54]. Preharvest fruit drop takes place when there are reduced level of auxin synthesis, proper supply of auxin or even their precursor i.e., Tryptophan helped plant in increased level of Auxin resulted in overcoming pre-harvest fruit drop [55]. Tryptophan application either foliar or soil applied both had significant influenced on reduced rate of flower buds, induced earlier flowering and also reduced pre-harvest fruit drop [31]. Similar findings were found by [54] that reduction in flower drop facilitate least fruit drop.

Table 4. Number of fruits plant ${ }^{-1}$, Fruit drop (\%) and Length of Fruit $(\mathrm{cm})$ of chilli as influenced by Tryptophan with and without the application of NPK fertilizer

\begin{tabular}{|c|c|c|c|}
\hline Fertilizer (NPK) & Fruits number plant ${ }^{-1}$ & Fruit drop (\% age) & Fruit Length $(\mathrm{cm})$ \\
\hline With Fertilizer & $293.06 \mathrm{a}$ & $53.61 \mathrm{~b}$ & $8.66 \mathrm{a}$ \\
\hline Without Fertilizer & $290.89 b$ & $55.10 \mathrm{a}$ & $8.00 \mathrm{~b}$ \\
\hline LSD (0.05) & 1.24 & 1.34 & 0.27 \\
\hline \multicolumn{4}{|l|}{ Tryptophan $\left(\mathrm{mg} \mathrm{L}^{-1}\right)$} \\
\hline Control & $272.67 \mathrm{f}$ & $66.09 \mathrm{a}$ & $6.58 \mathrm{e}$ \\
\hline 0.5 & $278.17 \mathrm{e}$ & $60.96 \mathrm{~b}$ & $7.77 \mathrm{~d}$ \\
\hline 1.0 & $285.50 \mathrm{~d}$ & $56.09 \mathrm{c}$ & $8.57 \mathrm{~b}$ \\
\hline 1.5 & $318.17 \mathrm{a}$ & $38.80 \mathrm{f}$ & $10.04 \mathrm{a}$ \\
\hline 2.0 & $301.83 \mathrm{~b}$ & $51.18 \mathrm{e}$ & $8.80 \mathrm{~b}$ \\
\hline 2.5 & $295.50 \mathrm{c}$ & $53.02 \mathrm{~d}$ & $8.21 \mathrm{c}$ \\
\hline LSD (0.05) & 1.61 & 1.35 & 0.30 \\
\hline \multicolumn{4}{|l|}{ Interaction } \\
\hline Fert*Trp & NS & 1.91 & NS \\
\hline
\end{tabular}

The mean values with different alphabets are significantly variant at 5\% probability level.

\section{Length of Fruit (cm)}

Fruit length $(\mathrm{cm})$ of chilli as affected by

Tryptophan with and without the application of NPK fertilizer are shown in (Table 4). ANOVA presented that fruit length was considerably influenced by Tryptophan with 
and without the use of NPK fertilizer, and their interaction effect was non-significant. (Table 4) indicated that the treatment of plants with Tryptophan application at $1.5 \mathrm{mg}$ $\mathrm{L}^{-1}$ gave maximum fruit length $(10.04 \mathrm{~cm})$, while least fruit length $(6.58 \mathrm{~cm})$ was found in $0 \mathrm{mg} \mathrm{L}^{-1}$. As concerned with NPK fertilizer application maximum fruit length $(8.66 \mathrm{~cm})$ was noted in plots having NPK fertilizer, while least fruit length $(8.00 \mathrm{~cm})$ was noticed in plots without NPK fertilizer. Size and weight is a key morphological aspects of fruits which are useful for final yield and also for consumer acceptance [56]. Auxin or even their precursor helps in cell separation and cell enlargement resulted in increased rate of cell number that finally leading to greater fruit size [24]. Fruit with maximum length was also found in those plants that are treated with Tryptophan, while least fruit length was noted in plants that are untreated with Tryptophan [31]. The results are in support with the findings of [57] that Tryptophan application which is the precursor of IAA had proved considerable influenced in enhancing growth and yield of okra. Furthermore, [41] reported that longer fruits were record when NPK fertilizer were added at 100, 50 and 25 $\mathrm{kg} \mathrm{ha}{ }^{-1}$, while smaller fruit were noted in control treatment. High dose of NPK increased fruit length, beyond the given level, fruits start decreased in their size, excess of NPK fertilizer ultimately decreased fruit length. Similar results was given by [58] that optimum doses of NPK fertilizer to Brinjal plants induced fruits with maximum length.

\section{Fruit weight (g)}

Fruit weight (g) of chilli as influenced by Tryptophan with and without the use of NPK fertilizer are shown in (Table 5). ANOVA presented that fruit weight was considerably affected by Tryptophan with and without the addition of NPK fertilizer, while their interaction effect was non-significant. (Table $5)$ presented that those plants which were treated with Tryptophan at $1.5 \mathrm{mg} \mathrm{L}^{-1}$ had produced maximum fruit weight $(4.13 \mathrm{~g})$, while the least fruit weight (2.39 g) was noted in control or $0 \mathrm{mg} \mathrm{L}^{-1}$. As concerned with the NPK fertilizer application more fruit weight (3.58 g) was found in plots having NPK fertilizer, while least fruit weight ( $3.19 \mathrm{~g}$ ) was observed in plots having without NPK fertilizer. Individual fruit yield were increased with the percentage of 46.6 and $94.6 \%$ respectively when Tryptophan was applied foliar at $40 \mathrm{mg} \mathrm{kg}^{-1}$ and soil application at $10 \mathrm{mg} \mathrm{L}^{-1}$, while least individual fruit weight were found in plants to which Tryptophan was not added [31] further reported that Tryptophan formed alterations in plant root structure that resulted in enhancement of water and plant molecules uptake, which may have positive influence on plant growth and development. Positive impact of Tryptophan on crops growth and yield attributes may be due to Tryptophan or auxin uptake through plant roots from the soil or either its absorption through cuticles from plant leaves [59]. Similar results were cited by [60] that Tryptophan enhanced weight of Onion bulbs. The results are in support with [32] that higher fruits plant ${ }^{-1}$, individual fruit weight, seeds fruit ${ }^{-1}$ and yield plant $^{-1}$ was found in Chilli with balanced supply of NPK and Bio-fertilizers, while least numbers of data found in control. Similar results were also found by [61] that Nitrogen, Phosphorous and Potassium application enhanced the yield of potato tuber. 


\section{Fruit yield (tons ha-1)}

Mean data about fruit yield (tons $\mathrm{ha}^{-1}$ ) of chilli as affected by Tryptophan with and without the use of NPK fertilizer are placed in (Table 5). ANOVA revealed that fruit yield $\mathrm{ha}^{-1}$ was considerably affected by Tryptophan with and without the use of NPK fertilizer, their interaction effect was nonsignificant. (Table 5) showed that fruit yield ha $^{-1}$ as affected by Tryptophan, more fruit yield (7.25 tons $\mathrm{ha}^{-1}$ ) was noted in foliar application of Tryptophan at $1.5 \mathrm{mg} \mathrm{L}^{-1}$, while least fruit yield (3.60 tons $\mathrm{ha}^{-1}$ ) was found in control. As concerned with NPK fertilizer application, maximum fruit yield (5.86 tons $\mathrm{ha}^{-1}$ ) was noted in plots where NPK fertilizer were applied, while least fruit yield (5.07 tons ha-1) was observed in without NPK fertilizer plots. Chlorophyll play a key role in plant photosynthesis, with increase rate of photosynthesis increase in the rate of carbohydrates as well as photo-assimilates or photosynthates resulted in maximum crop yield [62]. Growth and yield of the plant is the outcome of balanced interaction among both vegetative and reproductive growth phases of the crops, with an increased rate of vegetative growth helps in enhancing yield parameters which resulted in maximum crop production [63]. Crop production is the main aim of growers in order to improve their productivity and to achieve quality crops [64]. Reduction in yield was recorded by [65] due to pre-harvest flower and fruit drop. Valencia orange tree when treated with foliar application of Tryptophan gave maximum yield, size and fruit weight, whereas least results were obtained in control, [66] further revealed that plants that are sprayed with maximum level of Tryptophan at 100 ppm gave least yield, while plant treated with minimum concentration of Tryptophan at 25 and 50 ppm gave maximum yield. Omogoye and Mubo [34] concluded from his research work that NPK fertilizer with the combine use of cow dung effected the production of chilli. The results are in accordance with the findings of [67].

\section{Total Soluble Solids ( ${ }^{\circ}$ Brix)}

Total soluble solids contents of chilli as influenced by Tryptophan with and without the application of NPK fertilizer are presented in (Table 5). ANOVA showed that TSS contents was considerably influenced by Tryptophan with and without the use of NPK fertilizer, and also by their interaction. (Table 5) presented that TSS contents as affected by Tryptophan, maximum TSS contents (5.60 ${ }^{\circ}$ Brix) was noted in Tryptophan at $1.5 \mathrm{mg} \mathrm{L}$ ${ }^{1}$, while least TSS contents (4.77 ${ }^{\circ}$ Brix) was recorded in $0 \mathrm{mg} \mathrm{L}^{-1}$. As concerned with the application of NPK fertilizer maximum TSS contents $\left(5.39^{\circ}\right.$ Brix) was recorded in NPK fertilizer applied plots, while minimum TSS contents (5.04 ${ }^{\circ}$ Brix) was observed in without NPK fertilizer plots. TSS is the determining factor of fruit quality [57]. Increased in TSS contents due to auxin formation that helps in stimulation of fruit development or Tryptophan, which is the physiological precursor of auxin that helps in improving synthesis of metabolites and their rapid translocation to fruit development from other parts of the plant [68]. TSS contents of fruit Capsicum was significantly influenced by recommended level of NPK fertilizer, that maximum TSS contents was noted in fruits that are treated with optimum dose of NPK, while least TSS contents was recorded in check plants [69]. These results are strongly 
supported with the findings of [70].

Ascorbic acid (mg 100g ${ }^{-1}$ )

Ascorbic acid contents of chilli as influenced by Tryptophan with and without the supply of NPK fertilizer are revealed in (Table 5). ANOVA disclosed that Ascorbic acid contents was considerably influenced by Tryptophan with and without the use of NPK fertilizer, whereas their interaction effect was non-significant. (Table 5) presented that the plants treated with Tryptophan at $1.5 \mathrm{mg} \mathrm{L}^{-1}$ gave maximum Ascorbic acid contents $\left(115.33 \mathrm{mg}^{100 \mathrm{~g}^{-1}}\right)$, while least $(103.50 \mathrm{mg}$ $100 \mathrm{~g}^{-1}$ ) was observed in $0 \mathrm{mg} \mathrm{L}^{-1}$. As concerned with the use of NPK fertilizer, more Ascorbic acid contents $(110.78 \mathrm{mg}$ $100 \mathrm{~g}^{-1}$ ) was found in plots having NPK fertilizer, while least $\left(105.67 \mathrm{mg}_{100 \mathrm{~g}^{-1}}\right)$ was found in plots without NPK fertilizer. Ascorbic acid contents of sweet pepper vary

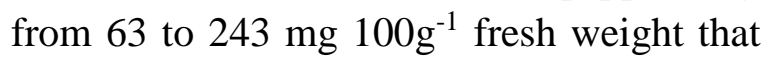

depends on the stage of fruit maturity [71]. Fruits of hot pepper that are eaten by humans are considered as the valued source of antioxidant, foliar application of Tryptophan proved positive impact on Ascorbic acid contents of hot pepper fruits, plants that are treated with Tryptophan gave quality fruits that attain maximum Ascorbic acid contents [45]. The results are in agreement with the findings of [43] that Ascorbic acid contents of tomato enhanced by foliar spray of Tryptophan. Fruits of Chilli after 60 days of harvesting was analysed for various biochemical constituents by [72] and found more Ascorbic acid contents in plants where NPK fertilizer were applied than control. Same results was found by [73] that Ascorbic acid contents of strawberry fruits was increased with optimum dose of NPK with the combination of Azotobacter.

Table 5. Fruit weight (g), Fruit yield ha ${ }^{-1}$ (tons), Total Soluble Solids $\left({ }^{\circ}\right.$ Brix) and Ascorbic acid $\left(\mathrm{mg}^{\left.100 \mathrm{~g}^{-1}\right)}\right.$ of chilli as influenced by Tryptophan with and without the application of NPK fertilizer

\begin{tabular}{|c|c|c|c|c|}
\hline Fertilizer (NPK) & $\begin{array}{c}\text { Fruit weight } \\
\text { (g) }\end{array}$ & $\begin{array}{l}\text { Fruit Yield } \\
\text { ha }^{-1} \text { (tons) }\end{array}$ & $\begin{array}{c}\text { TSS } \\
\left({ }^{\circ} \text { Brix }\right)\end{array}$ & $\begin{array}{c}\text { Ascorbic acid } \\
\left(\mathrm{mg} \mathrm{100g}^{-1}\right)\end{array}$ \\
\hline With Fertilizer & $3.58 \mathrm{a}$ & $5.86 \mathrm{a}$ & $5.39 \mathrm{a}$ & $110.78 \mathrm{a}$ \\
\hline Without Fertilizer & $3.19 \mathrm{~b}$ & $5.07 \mathrm{~b}$ & $5.04 \mathrm{~b}$ & $105.67 \mathrm{~b}$ \\
\hline LSD (0.05) & 0.34 & 0.69 & 0.16 & 2.04 \\
\hline \multicolumn{5}{|l|}{ Tryptophan $\left(\mathrm{mg} \mathrm{L}^{-1}\right)$} \\
\hline Control & $2.39 \mathrm{~d}$ & $3.60 \mathrm{~d}$ & $4.77 \mathrm{c}$ & $103.50 \mathrm{~d}$ \\
\hline 0.5 & $3.14 \mathrm{c}$ & $4.84 \mathrm{c}$ & $5.25 \mathrm{~b}$ & $107.17 \mathrm{bc}$ \\
\hline 1.0 & $3.75 \mathrm{~b}$ & $5.93 \mathrm{~b}$ & $5.19 \mathrm{~b}$ & $108.17 b c$ \\
\hline 1.5 & $4.13 \mathrm{a}$ & $7.25 \mathrm{a}$ & $5.60 \mathrm{a}$ & $115.33 \mathrm{a}$ \\
\hline 2.0 & $3.77 \mathrm{~b}$ & $6.01 \mathrm{~b}$ & $5.27 \mathrm{~b}$ & $110.00 \mathrm{~b}$ \\
\hline 2.5 & $3.16 \mathrm{c}$ & $5.17 \mathrm{~b}$ & $5.22 \mathrm{~b}$ & $105.17 \mathrm{~cd}$ \\
\hline LSD (0.05) & 0.18 & 0.38 & 0.14 & 3.01 \\
\hline \multicolumn{5}{|l|}{ Interaction } \\
\hline Fert*Trp & NS & NS & 0.20 & NS \\
\hline
\end{tabular}


The mean values with different alphabets are significantly variant at 5\% probability level.

\section{Conclusions and Recommendations}

It can be concluded based on the experimental results that; Fertilizer (NPK) at 100,60 and $25 \mathrm{~kg} \mathrm{ha}^{-1}$ respectively gave plants with a maximum height, maximum leaf area, branches plant $^{-1}$, stem diameter, fruit length, fruits plant ${ }^{-1}$, fruit weight, yield ha $^{-1}$, Total soluble solids, Ascorbic acid contents, early flowering, fruit harvesting and least fruit drop. Tryptophan at the rate of $1.5 \mathrm{mg} \mathrm{L}^{-1}$ produced a taller plant, greater leaf area, more branches plant $^{-1}$, stem diameter, earlier flowering, fruit harvesting, more fruits plant $^{-1}$, least fruit drop, fruit length, fruit weight, yield $\mathrm{ha}^{-1}$, TSS and Ascorbic acid contents of chilli. In the light of the outcomes and conclusions, it may be recommended that; Tryptophan at $1.5 \mathrm{mg} \mathrm{L}^{-}$ 1 and fertilizer (NPK) i.e., $100 \mathrm{~kg} \mathrm{~N}, 60 \mathrm{~kg}$ $\mathrm{P}_{2} \mathrm{O}_{5}$ and $25 \mathrm{~kg} \mathrm{~K}_{2} \mathrm{O}$ ha $^{-1}$ is recommended for getting a good crop of chilli under the agroecological conditions of District Mardan.

\section{Authors' contributions}

Conceived and designed the experiment: Rahman SU \& Nabi G, Performed the experiment: Rahman SU and Ali W, Analyzed the Data: Rahman SU \& Khan $\mathrm{MN}$, Contributed reagents/materials/analysis tools: Rukh S, Rahman MU \& Hilal M, Wrote the paper: Rahman SU, Shah FA \& Zaib S.

\section{References}

1. Parveez MA, Muhammad F \& Ahmad M (2000). Effect of Auxin Precursor Tryptophan on the Growth and Yield of Tomato (Lycopersicum esculentum L.). J Pak Biol Sci 3(7): 1154-1155.

2. Naz S, Anjum MA \& Ahmad I (2006). Growth of chilli (Capsicum annuum L.) $\mathrm{F}_{1}$ hybrid sky line-2 in response to different stages of transplants. J Res Sci 17: 91-95.

3. Malik MN (1994). Horticulture. In: Baloch AF (Eds.) Vegetable crops. National Book Foundation Islamabad. pp. 510-511.

4. Bosland PW (1992). Chilies a diverse crop. Horticulture, Technology. 2(1): 07-10.
5. Bhuvaneswari G, Sivaranjani S, Reeth \& Ramakrishnan K (2013). Application of Nitrogen and Potassium efficiency on the growth and yield of chilli (Capsicum annuum L.). Int J Cur Microb \& Appl Sci 2(12): 329-337.

6. Hazra P, Chattopadhyay A, Karmakar K \& Dutta S (2011). Modern technology in vegetable production. New India Publishing Agency, New Delhi, India. pp. 478.

7. Segnou J, Amougou A, Youmbi E \& Njoya J (2013). Effect of Chemical Treatments on Pests and Diseases of Pepper (Capsicum annuum L.). Greener J Agri Sci 3(1): 12-20.

8. Simmone AH, Simonne EH, Eitenmiller RR, Mills HA \& Green NR (1997). Ascorbic acid and vitamin-A contents in usually coloured bell peppers (Capsicum annuum L.). Food Comp Anal 10: 299-311.

9. Khan HA, Ayub CM, Pervez MA, Bilal RM, Shahid MA \& Ziaf K (2009). Effect of seed priming with $\mathrm{NaCl}$ on salinity tolerance of hot pepper (Capsicum annum L.) at seedling stage. Environ Exp Bot 60: 77-85.

10. Anonymous (2011-12). Statistical status report, National Horticulture Board, Gurgaon (Haryana), India.

11. Govt. of. Pakistan. MINFSR (2017-18). Fruits, vegetables and condiments statistics of Pakistan. Ministry of National food Security and Research Islamabad. pp. 17-18.

12. Alabi DA (2006). Effects of fertilizer phosphorus and poultry droppings treatments on growth and nutrient components of pepper (Capsicum annuum L.). Afr J Biotech 5(8): 671-677.

13. Erickson AN \& Makhart (2001). Flower production, fruit set and physiology of bell pepper during elevated temperature and vapour pressure deficit. J Amer Soc Hort Sci 126(6): 697-702.

14. Sarwar M, Arshad M, Martens DA \& Frankenberger WTJR (1992). Tryptophan dependent biosynthesis of auxins in soil. Plant Soil 147(2): 207-215. 
15. Zahir AZ, Malik MAR \& Arshad M (1999). Effect of auxins on the growth and yield of rice. Pak J Agri Sci 36: 3-4.

16. Frankenberger WTJR, Chang AC \& Arshad M (1990). Response of (Raphanus sativus L.) to the auxin precursor tryptophan applied to soil. Plant Soil 129(2): 235-241.

17. Davies PJ (1987). Plant hormones and their role in plant growth and development. Martinus Nijhoff Publishers Dordrecht, Netherlands.

18. Locassio SJF, Kell GA \& Martin FG (1981). Response of bell pepper to nitrogen source. $J$ Am Soc Hort Sci 106: 625-632.

19. Batal KM \& Smittle DA (1981). Response of bell pepper to irrigation, nitrogen and plant population. J Am Soc Hort Sci 106: 259-262.

20. Saskatchewan AM (1999). Functions of phosphorus in plants. Better Crops 83: 0106.

21. Hsiao C \& Lauchli A (1986). Role of potassium in plant-water relation and advances in plant nutrition. $2^{\text {nd }}$ ed. Praeger, New York. 281-312.

22. Waheedullah (1994). Vegetable package. Unpublished pamphlet. Agri. Res. Inst. Tarnab Peshawar. pp. 5.

23. Steels RGD, Torrie JH \& Dickie DA (1997). Principles and procedures of statistics. A biometric approach, $3^{\text {rd }}$ edit. USA. McGrawHill publishing company, Toronto. ISBN 10: 0070610282.

24. Tapdiya GH, Gawande PP, Ulemale PH, Patil RK \& Naware MS (2018). Effect of Growth Regulators on Quantitative Characters of Chilli (Capsicum annuиm L.) Int J Cur Micro Appl Sci 6: 2151-2157.

25. Vanderhoef N (1980). Auxin-regulated cell enlargement and there action at the level of gene expression. In Genome Organization and Expression in Plants. Leave, CJ (Eds.). Plenum New York. 159-173.

26. Hanan Z (2000). Effect of tryptophan and paclobutrazol on Caraway (Carum carvil L.) and Coriander (Coriandrum sativum L.) plants. M.Sc. Thesis. Fac. of Agri., Cairo.
27. Iman M, Talaat, Bekheta MA \& Mahgoub MH (2005). Physiological Response of Periwinkle Plants (Catharanthus roseus L.) to Tryptophan and Putrescine. Int J Agri \& Biol 7(2): 210-213.

28. Russell RS (1982). Plant root systems, $1^{\text {st }}$ (Eds.). ELBS, UK. pp. 16-17.

29. Chadha S, Rana SS \& Chaudhary DR (2006). Nutrient management in summer onion (Allium cepa $\mathrm{L}$.) under cold desert conditions of North-Western Himalayas. Ind J Agri Sci 76(10): 629-631.

30. Attoa GE, Wahba HE \& Farahat AA (2002). Effect of some amino acids and sulphur fertilization on growth and chemical composition of (Iberis amara L.). Plant Egy J Hort 29: 17-37.

31. Mustafa A, Hussain A, Naveed M, Ditta A, Nazli ZH \& Sattar A (2016). Response of okra (Abelmoschus esculentus L.) to soil and foliar applied tryptophan. $J$ Soil Environ 35(1): 76-84.

32. Rahman MA, Rahman MM, Begum MF \& Alam MF (2012). Effect of bio compost, cow dung compost and NPK fertilizers on growth, yield and yield components of Chilli. Int J of Bio Sci 2(1): 51-55.

33. Patil DR \& Patel MN (2010). Effect of seed treatment with $\mathrm{GA}_{3}$ and NAA on growth and yield of okra. Asian J Hort 5: 269-272.

34. Omogoye \& Mubo A (2015). Efficacy of NPK and Cow Dung Combinations on Performance of Chilli Pepper (Capiscum annиum L.) and their Influence on Soil Properties. J Agri Vet Sci 8(7): 31-35.

35. Khan MA, Abid M, Hussain $N$ \& Imran $T$ (2005). Growth and analysis of wheat (Triticum aestivium L.) cultivars under saline conditions. Int J Agri Biol 7(3): 508-510.

36. Nishanthi S \& Sutharsan S (2017). Effect of Integrated Use of Tryptophan and Chemical Fertilizer on Growth and Yield Performances of Radish (Rhaphanus sativus L.). Nat Sci Foun Colombo 11(2): 27-33.

37. Aziz NGB, Mahgoub NH \& Mazher AAM (2009). Physiological effect of phenylalanine 
and tryptophan on the growth and chemical constituents of (Antirrhium majus L.). Plants J App Sci 2: 399-407.

38. Rao SR, Qayyum A, Razzaq A, Ahmad M, Mahmood I \& Sher A (2012). Role of foliar application of salicylic acid and Tryptophan in drought tolerance of maize. J Ani Plant Sci 22(3): 768-772.

39. Leonard M, Kinet KM, Bodson M \& Bernier G (1983). Enhanced influenced development in tomato by growth substance treatments in relation to ${ }^{14} \mathrm{C}$ assimilate distribution. Physiol Plant Arun 57(1): 85-89.

40. Raza S, Kanwal S, Aziz T, Ali A, Parveen, Azhar M, Noor SU \& Wahla AQ (2014). Growth and yield responses of chilli (Capsicum annuum L.) to exogenously applied Tryptophan. Int J Mod Agri 3(2): 5155.

41. Jilani MS, Bakar A, Waseem K \& Kiran M (2009). Effect of Different Levels of NPK on the Growth and Yield of Cucumber (Cucumis sativus L.) Under the Plastic Tunnel. J Agri Sci 5(3): 99-101.

42. Naeem N, Irfan M, Khan J, Nabi G, Muhammad N \& Badshah N (2002). Influence of various levels of nitrogen and phosphorus on growth and yield of Chilli (Capsicum annum L.). Asian J Plant Sci 1: 599-601.

43. Parveez MA, Muhammad F \& Ahmad M (2000). Effect of Auxin Precursor Tryptophan on the Growth and Yield of Tomato (Lycopersicum esculentum L.). J Pak Biol Sci 3(7): 1154-1155.

44. Waseem K, Kamran QM \& Jilani MS (2008). Effect of different levels of nitrogen on the growth and yield of Cucumber (Cucumis sativus L.). J Agric Res 46: 259266.

45. Ghoname AA, Mona G, Dawood, Mervat S, Sadak, Amira \& Hegazi MA (2010). Improving nutritional quality of hot pepper (Capsicum annuum L.) plant via foliar application with arginine or tryptophan or glutathione. J Biol Chem Environ Sci 5(1): 409-429.

46. El-Tantawy EM (2009). Behaviour of tomato plants as affected by spraying with chitosan and amino fort as natural stimulator substances under application of soil organic amendments. Pak J Biol Sci 12: 1164-1173.

47. Zhong XH, Hui SX, Wei MD, Fei HY \& Hui DS (2004). Study on the effects of tryptophan on the growth and fruit quality of strawberry cv. Sophie. J Fruit Sci 21(6): 565568.

48. Dawood MG \& Sadak MS (2007). Physiological response of canola plants (Brassica napus L.) to tryptophan or benzyladenine. Lucrari Stiintifice 50(9): 198-207.

49. Frankenberger WTJR \& Arshad M (1991). Yield of (Capsicum annuum L.) to auxin precursor Tryptophan applied to plant. PGRs Quarterly. 19: 231-240.

50. Vazirimehr MR \& Regi K (2014). Effect of salicylic acid in Agriculture. Int J Plant Animal and Environ Sci 4(2): 291-296.

51. Khan AQ, Iqbal M, Jilani MS, Ghafoor A \& Waseem K (2001). Effect of seedling transplantation dates on the yield of tinda Gourd (Citullus vulgaris L.). J Biol Sci 1(4): 235-237.

52. Nawaz AM, Waqar A, Saeed A \& Mumtaz $\mathrm{K}$ (2008). Role of growth regulators on preharvest fruit drop, yield and quality in kinnow mandarin. Pak J Bot 40(05): 19711981.

53. Shil S \& Nath D (2016). Effect of NAA on growth and yield attributes of chilli during winter season under climatic conditions of Tripura. Int J Agri Sci 8(51): 2192-2193.

54. Sakamoto MI, Munemura R, Tomita \& Kobayashi K (2008). Plant Signal Behaviour. 3(11): 1014-1015.

55. Luckwill LC (1957). Hormonal aspects of fruit development in higher plants. Symp Soc Exp Biol 11: 63-85.

56. Prasad RN, Sanjay KS, Yadava RB \& Chaurasia SNS (2013). Effect of $\mathrm{GA}_{3}$ and 
NAA on growth and yield of tomato. Veg. Sci 40(2): 195-197.

57. Abeles FB, Morgan PW \& Saltveit MEJR (1992). Ethylene in plant biology, $2^{\text {nd }}$ (Eds.) San Diego: Academic Press.

58. Jilani MS, Afzaal MF \& Waseem K (2008). Effect of different nitrogen levels on growth and yield of brinjal. J Agri Res 46: 245-251.

59. Abbas SH, Sohail M, Saleem M, Mahmood T, Aziz I, Qamar M, Majeed A \& Arif M (2013). Effect of Tryptophan on plant weight and pod weight in chickpea under rain fed conditions. Sci and Tech Div 32(4): 277-280.

60. Hussein MM, Faham SY \& Alva AK (2014). Role of foliar application of Nicotinic acid and Tryptophan on plants response to Salinity Stress. J Agri Sci 6(8): 41-51.

61. Zaied KA, Abdelhady AH, Aida HA \& Nassef MA (2003). Yield and Nitrogen as stimulation of winter wheat inoculated with new recombinant inoculants of rhizobacteria. Pak J Biol Sci 6(4): 344-358.

62. Revenappa U, Nalawadi G \& Chetti MD (1997). Karnataka J Agri Sci 10(4): 10441048.

63. Bhati FN \& Prasad VM (2005). Varietal performance of fenugreek (Trigonella foenum-graecum L.) under Allahabad Agro climatic conditions. Bioved 15: 45-48.

64. Ortas I (2013). Influence of nitrogen and potassium fertilizer rates on pepper and tomato yield and nutrient uptake under field conditions. Sci Res and Essays 8(23): 10481055.

65. Choudhary BR, Fageria MS \& Dhaka RS (2002). Role of growth hormones in chillies. Agri Rev 23(2): 145-148.

66. Ahmed HH, Khalil MK, Rahman AM \& Hamed NA (2012). Effect of Zinc,
Tryptophan and Indole Acetic Acid on Growth, Yield and Chemical Composition of Valencia Orange Trees. J Appl Sci Res 8(2): 901-914.

67. Ewulo BS, Hassan KO \& Ojeniyi SO (2007). Comparative Effect of Cow dung Manure on Soil and Leaf Nutrient and Yield of Pepper. Int J Agri Res 2: 1043-1048.

68. Singh K, Madhu S \& Shailesh KS (2017). Effect of Plant Growth Regulators on Fruit Yield and Quality of Guava (Psidum guajava L.) cv. Allabad Safeda. J pure and Appl Micro 11(2): 1149-1154.

69. Thakur L, Bhatt L, Maurya SK \& Kumar U (2015). Standardization of NPK through fertigation in Capsicum with or without mulch in naturally ventilated polyhouse. Annals of Plant and Soil Res 17: 586-589.

70. Gupta AJ, Ahmad MF \& Bhat FN (2010). Studies on yield, quality, water and fertilizer use efficiency of capsicum under drip irrigation and fertigation. Ind J Hort 67(2): 213-218.

71. Lee Y, Howard LR \& Villalon B (1995). Flavonoids and antioxidant activity of fresh pepper (Capsicum annum L.) cultivars. $J$ Food Sci 60: 473-476.

72. Densilin DM, Srinivasan S, Manju P \& Sudha S (2011). Effect of individual and combined application of bio fertilizers, inorganic fertilizer and vermicompost on the biochemical constituents of Chilli. J Biofert \& Biopest 2(1): 01-03.

73. Nair AS, Shiva KN, Medhi RP, Singh DR \& Beena SJ (2002). Effect of fertility levels and spacing on gerbera. National symposium on Floriculture in the New Millennium, Uttakmund. 